Please complete this form and email or hand it to your librarian or library representative:

\title{
TO THE LIBRARIAN
}

I recommend the following book for purchase by the library. The book is very relevant to the work in our department. Please consider this book for purchase at the earliest opportunity.

Title: Metagenomics: Current Advances and Emerging Concepts

Edited by: Diana Marco

Publisher: Caister Academic Press

Book: 978-1-910190-59-3. Ebook: 978-1-910190-60-9

Available worldwide from:

* Caister Academic Press https://www.caister.com/order or from all good book shops and library suppliers

Name:

Department:

Signature:

\section{CURRENT BOOKS OF INTEREST:}

Lyme Disease and Relapsing Fever Spirochetes: Genomics, Molecular Biology, Host Interactions and Disease Pathogenesis Edited by: Justin D. Radolf and D. Scott Samuels. January 2021. 978-1-913652-61-6 978-1-913652-62-3.

Veterinary Vaccines: Current Innovations and Future Trends

Edited by: Laurel J. Gershwin and Amelia R. Woolums. October 2020. 978-1-913652-59-3 978-1-913652-60-9.

Climate Change and Microbial Ecology: Current Research and Future Trends (Second Edition)

Edited by: Jürgen Marxsen. October 2020. 978-1-913652-57-9 978-1-913652-58-6.

Alphaherpesviruses: Molecular Biology, Host Interactions and Control

Edited by: Ekaterina E. Heldwein and Gregory A. Smith. August 2020. 978-1-913652-55-5 978-1-913652-56-2.

Legionellosis Diagnosis and Control in the Genomic Era

Edited by: Jacob Moran-Gilad and Rachel E. Gibbs. July 2020. 978-1-913652-53-1 978-1-913652-54-8.

Bacterial Viruses: Exploitation for Biocontrol and Therapeutics

Edited by: Aidan Coffey and Colin Buttimer. June 2020. 978-1-913652-51-7 978-1-913652-52-4.

Microbial Biofilms: Current Research and Practical Implications

Edited by: Arindam Mitra. February 2020. 978-1-912530-32-8 978-1-912530-33-5. 